\title{
Twenty-five plus years of an RNA addiction
}

\section{JOHN J. ROSSI}

Department of Molecular and Cellular Biology and Irell and Manella Graduate School of Biological Sciences, Beckman Research Institute of the City of Hope, Duarte, California 91010, USA

My entry into the RNA world came as for many others via studies of pretransfer RNA processing. The early RNA processing meetings were primarily about small noncoding RNAs. I have an interesting reflection from one of these early RNA meetings that involves a back-to-back talk which I had with John Abelson. John preceded me. We had our slides in the same carousel. John started talking while my slides were projected. Alex Rich realized right away that the slides were not John's. He stood up and declared that John was such an accomplished speaker that he could lecture using someone else's slides. In the early 1980 s several groups described interruptions in the primary coding sequences for tRNAs in yeast. This to me was the beginning of the most exciting era of RNA biology. The tRNA findings were followed closely by similar discoveries in protein encoding and rRNA encoding genes. The notion of the gene as an uninterrupted coding entity was shattered. The discoveries of intervening sequences created an explosion of new and exciting research within the RNA world. The major challenge was elucidation of the mechanisms by which the precise removal of intervening sequences from primary transcripts and splicing of the mature coding sequences took place.

From this point on, the RNA meetings became the most exciting meetings in the biological sciences. The early RNA processing meetings were held at Cold Spring Harbor in Blackford Hall which quickly became undersized for the huge crowds who often watched the talks remotely via closed circuit television in other rooms of the Cold Spring Harbor campus. The growth of interest in RNA processing necessitated moving the meetings to more accommodating locations such as Keystone, Colorado and the University of Wisconsin. The meetings became so interesting and informative that I could barely wait until the next meeting was held to learn about progress in the processing of RNAs which largely focused on RNA splicing mechanisms. The abstract books were treasures to be protected and saved for our colleagues to peruse. The discoveries of snRNAs as splice site sequence recognition components of the splicing apparatus and the first descriptions of catalytic RNAs such as the group I in-

\footnotetext{
Corresponding author: jrossi@coh.org

Article and publication date are at http://www.rnajournal.org/cgi/doi/ 10.1261/rna.050120.115. Freely available online through the RNA Open Access option.
}

trons and the RNAseP RNA completely changed our paradigms for the roles of RNA in cells. The real explosion of popularity of the field came following the first descriptions of alternative splicing which drew investigators from the fields of neurosciences and cancer biology to the RNA processing meetings. Alternative splicing helped explain how a relatively small number of vertebrate genes could result in such great protein diversity. I recall the meeting in Madison where the idea of forming an RNA society with its own journal was put forth by Tom Cech. This was truly a momentous moment for those who studied RNA processing. The early meetings of the Society were so heavily attended that for those arriving late for talks the only seating available was on the stairs of the meeting auditoriums. Abstract books were used to save seats and spots on the stairs. The books were so frequently pilfered that we were instructed to write our names and addresses on the covers.

Alternative splicing brought the field of RNA processing into the mainstream of biomedical sciences.

The discovery of catalytic RNAs in the 1980's triggered a new wave of interest in RNA applications as genetic and biomedical tools. The field became so active that a number of satellite meetings were organized to supplement the main Society meeting. My own research transitioned from studies of premessenger RNA splicing to biomedical applications of ribozymes. I was inspired to study therapeutic applications of hammerhead ribozymes following a lecture by Bob Simons at an RNA meeting in Keystone, Colorado. In his talk he suggested that the self-cleaving plant viroid motifs might be engineered to act in trans. Bob projected a map of Australia to depict the location where the plant viroids that contained self-cleaving domains were discovered. The location was Adelaide which he described with his usual candor as being in the crotch of Australia.

I became intimately involved in following the developments in the RNA world. The early theoretical proposals that the ribosome was a ribozyme were followed by experimental validation of this important concept. I still recall the meeting when the first experimental data for a rRNA catalyzed trans-peptidation reaction was presented by Harry

(C) 2015 Rossi This article, published in $R N A$, is available under a Creative Commons License (Attribution-NonCommercial 4.0 International), as described at http://creativecommons.org/licenses/by-nc/4.0/. 
Noller. The RNA world continued to thrive and expand with the discovery of RNA interference and micro RNAs.

Today, I see a huge new interest in RNA biology because of the widespread prevalence of micro RNA mediated post transcriptional gene regulation in nature. New roles for small RNAs in the regulation of gene expression continue to be described for post-transcriptional as well as transcriptional regulation of gene expression. The development of RNA as a therapeutic agent for regulating gene expression in the treatment of diseases such as cancer and AIDS has provided new hope for treatment of these diseases. A new genre of biotech companies focusing on therapeutic applications of small RNAs has come about because of recent discoveries of small RNA functions. Amazingly, RNA plays a key role even in gene editing and telomere maintenance. The ability of RNA to form Watson-Crick base pairs with other RNAs as well as DNA provides great specificity for RNA to function as a regulatory mediator of nucleic acid structure, function, and gene and transcript targeting.

The ability of RNAs to take on infinite shapes has resulted in a wide range of protein interactions. RNA aptamers provide a great example of the plasticity of RNA structures. Every meeting of the RNA Society reveals new and exciting roles for RNA in nature. The journal RNA is one of those journals that are fun and exciting to read cover to cover. The first 20 years have truly been exciting with lots of surprises. One can only surmise that more surprises are yet to come. RNA research has become an exciting and critically important component of biological research and no longer plays second fiddle to DNA and proteins. 

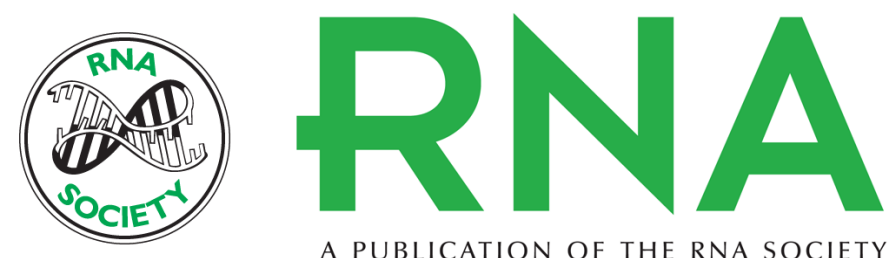

A PUBLICATION OF THE RNA SOCIETY

\section{Twenty-five plus years of an RNA addiction}

John J. Rossi

RNA 2015 21: 721-722

Open Access Freely available online through the RNA Open Access option.

Creative This article, published in RNA, is available under a Creative Commons License Commons (Attribution-NonCommercial 4.0 International), as described at

License http://creativecommons.org/licenses/by-nc/4.0/.

Email Alerting Receive free email alerts when new articles cite this article - sign up in the box at the Service top right corner of the article or click here.

To subscribe to $R N A$ go to:

http://rnajournal.cshlp.org/subscriptions

(C) 2015 Rossi; Published by Cold Spring Harbor Laboratory Press for the RNA Society 